\title{
Comparative study and meta-analysis of meta-analysis studies for the correlation of genomic markers with early cancer detection
}

\author{
Zoi Lanara ${ }^{1,2 \dagger}$, Efstathia Giannopoulou ${ }^{3 \dagger}$, Marta Fullen ${ }^{4}$, Evangelos Kostantinopoulos ${ }^{2}$, Jean-Christophe Nebel ${ }^{4}$, \\ Haralabos P Kalofonos ${ }^{3}$, George P Patrinos ${ }^{2}$ and Cristiana Pavlidis ${ }^{2^{*}}$
}

\begin{abstract}
A large number of common disorders, including cancer, have complex genetic traits, with multiple genetic and environmental components contributing to susceptibility. A literature search revealed that even among several meta-analyses, there were ambiguous results and conclusions. In the current study, we conducted a thorough meta-analysis gathering the published meta-analysis studies previously reported to correlate any random effect or predictive value of genome variations in certain genes for various types of cancer. The overall analysis was initially aimed to result in associations (1) among genes which when mutated lead to different types of cancer (e.g. common metabolic pathways) and (2) between groups of genes and types of cancer. We have meta-analysed 150 meta-analysis articles which included 4,474 studies, 2,452,510 cases and 3,091,626 controls (5,544,136 individuals in total) including various racial groups and other population groups (native Americans, Latinos, Aborigines, etc.). Our results were not only consistent with previously published literature but also depicted novel correlations of genes with new cancer types. Our analysis revealed a total of 17 gene-disease pairs that are affected and generated gene/ disease clusters, many of which proved to be independent of the criteria used, which suggests that these clusters are biologically meaningful.
\end{abstract}

Keywords: Cancer, Meta-analysis, Gene, Association, Interaction, Single-nucleotide polymorphism, Alleles, Clustering

\section{Introduction}

Cancer is the result of a complicated process that involves the accumulation of both genetic and epigenetic alterations in various genes [1]. The somatic genetic alterations in cancer include point mutations, small insertion/deletion events, translocations, copy number changes and loss of heterozygosity [2]. These changes either augment the action and/or expression of an oncoprotein or silence tumour suppressor genes. Single-nucleotide polymorphism (SNP) is the most common form of genetic variation in the human genome. Although common SNPs for disease prediction are not ready for widespread use [3], recent genome-wide association studies (GWASs) using high-throughput techniques have identified regions of the

\footnotetext{
* Correspondence: chpavlidou@upatras.gr

'Equal contributors

${ }^{2}$ School of Health Sciences, Department of Pharmacy, University of Patras, University Campus, Rio, Patras 26504, Greece

Full list of author information is available at the end of the article
}

genome that contain SNPs with alleles that are associated with increased risk for cancer such as FGFR2 in breast cancer [4-7].

The knowledge on gene mutations that predispose tumour initiation or tumour development and progress will give an advantage in cancer patients' treatment. Despite the complexity and variability of cancer genome, numerous studies have examined the correlation of genome variation with cancer development and progression [8]. However, ambiguous results have been generated from the attempt to link genome variants with cancer prediction or detection. A literature search revealed that even among several meta-analyses, there were unclear results and conclusions.

We have, therefore, conducted a thorough metaanalysis of meta-analysis studies previously reported to correlate the random effect or predictive value of genome variations in certain genes for various types of cancer. The aim of the overall analysis was the detection of

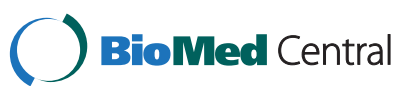


correlations (1) among genes whose mutation might lead to different types of cancer (e.g. common metabolic pathways) and (2) between groups of genes and types of cancer.

\section{Methods}

We performed a thorough field synopsis by studying published meta-analysis studies involving the association of various types of cancer with SNPs located in certain genomic regions. For each published meta-analysis included in our study, we also investigated the number of patients (cases) and controls, date, type of study, study group details (e.g. gender, race, age, etc.), measures included, allele and genotype frequency and also the outcome of each study, i.e. if there was an association or not, the interactions noticed in each of these studies, etc.

We have meta-analysed 150 meta-analysis articles (Additional file 1), which included 4,474 studies, 2,452,510 cases and 3,091,626 controls (5,544,136 individuals in total). The meta-analyses that have been meta-analysed included various racial groups, e.g. Caucasians, Far Eastern populations (Asian, Chinese, Japanese, Korean, etc.), African-American and other population groups (native Americans, Latinos, Aborigines, etc.). Three types of studies were included: (1) pooled analysis, (2) GWAS and (2) other studies, e.g. search in published reports. Collected data consisted of a list of genes, genomic variants and diseases with a known genotype-phenotype association (whether or not a given variation has an impact on susceptibility to a given disease). The principle of our study was to use data mining techniques to find groups (referred to as clusters hereafter) of genes or diseases that behave similarly according to related data. Such groupings will make it possible to find different cancer types susceptible to similar genotypes as well as different genes associated to similar cancer types. Furthermore, our approach would facilitate predicting whether susceptibility to one type of cancer may be indicative of predisposition to another cancer type. Moreover, the association between a group of genes and a given phenotype may suggest that these genes interact or belong to the same biochemical pathway. In order to allow data mining analysis, genotype-phenotype associations had to be classified within a fixed set of categories, i.e. yes/small yes/may/no. Moreover, genes or diseases with fewer than two entries were not considered in our analysis since their clustering would not be meaningful.

Then, data were processed using a state-of-the-art general purpose clustering tool, CLUTO [9]. Data analysis consisted in finding the tightest and most reliable groupings. Since CLUTO offers a wide range of methods, and many different scoring schemes can be used to estimate similarity between genotypes or phenotypes, cluster reliability was assessed by their robustness to clustering criteria (details are provided in Additional file 1). As a consequence, each putative association has been qualified as either 'highly consistent' or 'moderately consistent'. The biological significance of those clusters was, first, evaluated using the Search Tool for the Retrieval of Interacting Genes/Proteins (STRING) [10,11], a biological database and web resource of known and predicted protein-protein interactions. The STRING database contains information from numerous sources, including experimental data, computational prediction methods and public text collections. It is widely accessible, and it is regularly updated. Second, literature research was performed to complete this initial evaluation.

\section{Results and discussion}

In this study, we performed a meta-analysis of published meta-analysis studies to investigate possible correlations among genes and SNPs and various types of cancer, as well as among gene-gene and/or gene-environmental interactions. Furthermore, an advanced literature research was applied in order to evaluate our results obtained from our meta-analysis. Our data were not only consistent with previously published literature but we have also depicted novel correlations of genes with new types of cancer. Our analysis showed a total of ten cancer-related genes that are affected (Table 1).

\section{Correlation of SNPs' genes with various types of cancer}

The association highlighted by our meta-analysis between the CYP2E1 gene and colorectal cancer (CRC), head and neck cancer (HNC) and liver cell carcinoma (LLC) is supported by published data [33-39,44,121]. An additional literature search to evaluate our initial results revealed novel correlations of the gene combination CYP2E1 and GSTM1 with prostate cancer (PC) susceptibility, lung cancer (LC) and bladder cancer (UBC) as shown in Table 2 [126-128]. A similar correlation was found in CRC using a knockdown model $[32,40,41]$. Studies not only confirm the possibility of association between the CCND1 gene and breast cancer (BC) [25] but also suggest involvement with squamous cell carcinoma (SCC), oesophageal cancer (EC), oral cancer (OC) and malignant glioma (MG), as arisen from the interaction between the CCND1 and CCND3 genes [26,122-124]. This is further corroborated in mouse model studies that show association of CCND1 with BC [25,27-31,153] and PC [125].

Moreover, as far as the ERCC2 is concerned along with the association of ERCC1 gene with BC and LC which is already confirmed [14-17,21,22], we have also identified from our further literature search on humans the existence of an association with $\mathrm{OC}$ [26] and with HNC [129-131]. There were no similar mouse studies that could confirm or overrule our findings.

Our findings regarding the GSTP1 gene are confirmed by the published literature [39,46-55]. Furthermore, we 
Table 1 Summary of genes and SNPs identified by meta-analysis to be positively correlated with various cancers

\begin{tabular}{|c|c|c|c|c|c|}
\hline \multirow[t]{2}{*}{ Gene } & \multirow{2}{*}{$\begin{array}{l}\text { Cancer } \\
\text { type }\end{array}$} & \multicolumn{2}{|c|}{ SNPs } & \multirow[t]{2}{*}{ References } & \multirow{2}{*}{$\begin{array}{l}\text { Supporting } \\
\text { references }\end{array}$} \\
\hline & & rs number & Other name & & \\
\hline$E R C C 2$ & $B C$ & rs13181 & p.K715Q & {$[12,13]$} & [14-17] \\
\hline ERCC2 & $B C$ & rs1799793 & p.D312N & {$[12,18]$} & [14-16] \\
\hline$E R C C 2$ & LC & rs13181 & p.K751Q & {$[19,20]$} & {$[17,21,22]$} \\
\hline$E R C C 2$ & LC & rs1799793 & p.D312N & [23] & {$[17,21,22]$} \\
\hline CCND1 & $\mathrm{BC}$ & rs603965 & c. $870 G>A$ & [24] & {$[25-31]$} \\
\hline CYP2E1 & CRC & rs3813867 & NA & [32] & {$[32-41]^{a}$} \\
\hline CYP2E1 & $\mathrm{HNC}$ & rs3813867 & NA & {$[42,43]$} & {$[44]$} \\
\hline CYP2E1 & $\mathrm{HNC}$ & rs6413432 & NA & {$[42]$} & {$[44]$} \\
\hline GSTP1 & CRC & rs1695 & p.1105V & {$[45]$} & {$[39,46-55]$} \\
\hline IL6 & $B C$ & rs1800795 & c. $-174 \mathrm{G}>\mathrm{C}$ & {$[56,57]$} & \\
\hline MTHFR & GC & rs1801131 & C.1298A>C & [58] & {$[59,60]^{b}$} \\
\hline MTHFR & $\mathrm{BC}$ & rs1801131 & c. $677 C>$ T, c.1298A>C & {$[61,62]$} & {$[63,64]$} \\
\hline SOD2 & $B C$ & rs4880 & p.V16A, p.A9V & {$[62,65,66]$} & \\
\hline TGFB1 & $B C$ & rs1800469 & NA & {$[67-69]$} & \\
\hline TGFB1 & $B C$ & rs1800470 & NA & {$[67,70-73]$} & \\
\hline TGFB1 & $B C$ & rs1982073 & NA & [74] & {$[64,75-77]$} \\
\hline TP53 & $B C$ & rs1042522 & p.R72P & {$[78,79]$} & {$[80-94]$} \\
\hline TP53 & UBC & rs1042522 & p.R72P & [95] & [96-100] \\
\hline TP53 & CRC & rs1042522 & p.R72P & [78,101-103] & [104-108] \\
\hline TP53 & CRC & rs17878362 & NA & [78] & [104-108] \\
\hline TP53 & $\mathrm{EC}$ & rs1042522 & p.R72P & {$[109,110]$} & [111] \\
\hline TP53 & LC & rs1042522 & p.R72P & [78] & [112-117] \\
\hline TP53 & LC & rs17878362 & NA & [78] & [112-117] \\
\hline VEGFA & $\mathrm{BC}$ & rs3025039, rs699947 & $c .936 C>T, c .-2578 C>A$ & {$[20,45,118,119]$} & [120] \\
\hline
\end{tabular}

These findings are supported by the published literature. ${ }^{a}$ For a different SNP (rs1329149); ${ }^{b}$ for c.677C $>$ T and c.1298A $>$ C. NA not available.

have noticed an association with $\mathrm{PC}$ derived from the combination of GSTM1 and CYP1A1 [126,128,132,133]. Likewise, previous experimental evidence supports the association we found between the MTHFR gene and BC, basal cell carcinoma (BCC) $[63,134]$ and gastric cancer (GC) $[59,60]$. An association was also found between MTHFR gene with other types of cancer, such as acute lymphoblastic leukaemia (ALL) [135,136,154], LC [137], UBC coming from interaction between $C T H$ and GSTM1 [138], CRC [139], non-Hodgkin's lymphoma (NHL) [140,141], BC [64] and HNC [142]. Specifically, in the case of NHL, the gene combination of MTHFR and TYMS might influence the susceptibility to $N H L$ $[140,141]$.

Concerning TGFB1, apart from the $\mathrm{BC}$ [64] that was confirmed from the results of our further literature search on humans and on mouse model [75,76], we have noticed also the following associations with gastric dysplasia, LC, pancreatic cancer (PanC) and BC [77,143-146]. Also, an association of TGFB1 with CRC was found using a mouse model [147].
In addition for TP53 gene, we have observed in the results of our meta-analysis that it is associated with $\mathrm{BC}$, UBC, CRC, EC and LC [80-87,96-100,104-108,111113,149]. We have observed also that TP53 gene might be associated with OC $[88,148]$, too. Concerning the literature research on knockout mice, we have confirmed the associations with BC [89-94] and LC [114-117], and we have found also associations with ovarian cancer (OVCa) [150], GC [151] and OC [152]. Moreover for the VEGFA gene, based on further literature TGFB1 research, we have confirmed the association with $\mathrm{BC}$ [120], but we had not found any other evidence supporting the association with other types of cancer.

\section{Correlations between groups of genes and various types of cancer}

We have examined and confirmed the highly consistent gene clustering results over further literature search via STRING. Our search revealed additional types of cancer, except from the types that we have studied in our metaanalysis that seems to be related with pair of genes. 
Table 2 Summary of genes and SNPs identified by further literature search as positively correlated with various cancers

\begin{tabular}{|c|c|c|c|c|}
\hline \multirow[t]{2}{*}{ Gene } & \multirow{2}{*}{$\begin{array}{l}\text { Cancer } \\
\text { type }\end{array}$} & \multicolumn{2}{|c|}{ SNPs } & \multirow[t]{2}{*}{ References } \\
\hline & & rs number & Other name & \\
\hline CCND1 & OC & rs603965 & $c .870 G>A$ & {$[26,122-124]$} \\
\hline CCND1 & PC & rs603965 & $c .870 G>A$ & {$[125]$} \\
\hline CYP2E1 & PC & NA & NA & [126] \\
\hline CYP2E1 & LC & NA & NA & {$[127]$} \\
\hline CYP2E1 & UBC & NA & NA & [128] \\
\hline CYP2E1 & OC & NA & NA & {$[40]$} \\
\hline ERCC2 & OC & rs1799793, rs13181 & p.D312N, p.K751Q & {$[23]$} \\
\hline$E R C C 2$ & HNC & rs1799793, rs13181 & p.D312N, p.K751Q & [129-131] \\
\hline GSTP1 & PC & rs1695 & p.1105V & {$[126,128,132,133]$} \\
\hline MTHFR & $\mathrm{BCC}$ & rs1801131 & c.677C > T, c.1298A>C & [134] \\
\hline MTHFR & ALL & rs1801131 & c.677C > T, C.1298A>C & {$[59,135,136]$} \\
\hline MTHFR & LC & rs1801131 & c. $677 C>$ T, C.1298A $>C$ & [137] \\
\hline MTHFR & UBC & rs1801131 & c.677C > T, C.1298A>C & [138] \\
\hline MTHFR & $\mathrm{CC}$ & rs1801131 & c.677C > T, c.1298A >C & [139] \\
\hline MTHFR & $\mathrm{NHL}$ & rs1801131 & c.677C > T, C.1298A>C & {$[140,141]$} \\
\hline MTHFR & HNC & rs1801131 & c.677C > T, c.1298A >C & {$[142]$} \\
\hline TGFB1 & GC & rs1982073 & c. $+29 C>T$ & [143] \\
\hline TGFB1 & LC & rs1982073 & C. $+29 C>T$ & [144] \\
\hline TGFB1 & PC & rs1982073 & c. $+29 C>T$ & [145] \\
\hline TGFB1 & PC & rs1982073 & c. $+29 C>T$ & [146] \\
\hline TGFB1 & CRC & rs1982073 & c. $+29 C>T$ & {$[147]$} \\
\hline TP53 & EmCa & rs1042522/rs17878362 & p.R72P & [148] \\
\hline TP53 & PC & rs1042522/rs17878362 & p.R72P & {$[114,149]$} \\
\hline TP53 & OVCa & rs1042522/rs17878362 & p.R72P & [150] \\
\hline TP53 & GC & rs1042522/rs17878362 & p.R72P & [151] \\
\hline TP53 & OC & rs1042522/rs17878362 & p.R72P & {$[152]$} \\
\hline
\end{tabular}

NA not available.

STRING database reports binding interaction between GSTP1 and GSTM1 genes, activating interaction between MMP2 and EGF genes, between VEGFA and $I L 1 B$ genes and between MMP-9 and IL8 genes (Table 3). The application of our machine learning method has highlighted that those pair of genes have similar association profiles and, therefore, might be involved in the same pathways. The genes that do not appear in the associations do not probably correlate with the presence of a certain type of cancer.

First, in our meta-analyses, we observed that the interaction between IL6 and TGFB1 genes was associated to the following types of cancer: BC, CRC, GC, LC and PC as shown in Table 4. Although further literature search on humans could not validate our highly consistent results, we discovered that these interactions are associated to additional types of cancer, such as HNC [187], CRC [158], renal cancer (RC), small cell lung cancer
Table 3 Putative gene-gene associations with various cancer types

\begin{tabular}{|c|c|c|c|c|c|}
\hline \multicolumn{2}{|c|}{$\begin{array}{c}\text { Gene } \\
\text { associations } \\
\end{array}$} & \multirow[t]{2}{*}{$\begin{array}{l}\text { Considered } \\
\text { phenotypes }\end{array}$} & \multirow[t]{2}{*}{ Comments } & \multirow[t]{2}{*}{$\begin{array}{c}\text { STRING } \\
\text { confirmation }\end{array}$} & \multirow[t]{2}{*}{$\begin{array}{c}\text { Literature } \\
\text { confirmation }\end{array}$} \\
\hline $\begin{array}{c}\text { Gene } \\
1\end{array}$ & $\begin{array}{c}\text { Gene } \\
2\end{array}$ & & & & \\
\hline GSTP1 & GSTM1 & 4 & & $\begin{array}{l}\text { Binding } \\
\text { interaction }\end{array}$ & $\begin{array}{l}\text { [Reference]: } \\
\text { study type }\end{array}$ \\
\hline TGFB1 & IL6 & 5 & $\begin{array}{c}4 \text { of } 5 \\
\text { based on } \\
\text { 'yes' }\end{array}$ & & \\
\hline MMP2 & $E G F$ & 3 & $\begin{array}{l}\text { Based on } \\
\text { 'yes' }\end{array}$ & $\begin{array}{l}\text { Activating } \\
\text { interaction }\end{array}$ & \\
\hline VEGFA & $I L 1 B$ & 2 & & $\begin{array}{l}\text { Activating } \\
\text { interaction }\end{array}$ & \\
\hline MMP9 & IL8 & 4 & $\begin{array}{l}\text { Based on } \\
\text { 'may' }\end{array}$ & $\begin{array}{l}\text { Activating } \\
\text { interaction }\end{array}$ & $\begin{array}{l}\text { KEGG: same } \\
\text { process }\end{array}$ \\
\hline MMP1 & MMP3 & 5 & $\begin{array}{l}\text { Based on } \\
\text { 'may' }\end{array}$ & & \\
\hline
\end{tabular}


Table 4 Summary of gene-gene interactions and the corresponding SNPs in these genes

\begin{tabular}{|c|c|c|c|c|c|c|c|c|c|}
\hline \multirow{2}{*}{$\begin{array}{c}\text { Gene } \\
1\end{array}$} & \multirow{2}{*}{$\begin{array}{c}\text { Gene } \\
2\end{array}$} & \multirow{2}{*}{$\begin{array}{l}\text { Cancer } \\
\text { type }\end{array}$} & \multicolumn{2}{|c|}{ SNP's gene 1} & \multicolumn{2}{|c|}{ SNP's gene 2} & \multirow{2}{*}{$\begin{array}{l}\text { References } \\
\text { (gene 1) }\end{array}$} & \multirow{2}{*}{$\begin{array}{l}\text { References } \\
\text { (gene 2) }\end{array}$} & \multirow{2}{*}{$\begin{array}{l}\text { Supporting } \\
\text { references }\end{array}$} \\
\hline & & & rs number & $\overline{\text { Other name }}$ & rs number & Other name & & & \\
\hline IL6 & TGFB1 & $B C$ & rs1800795 & C. $-174 G>C$ & rs1800469, rs1800470 & c. -509 C $>$ T, p.T29C & [56] & {$[67-70,72-74]$} & [155-157] \\
\hline IL6 & TGFB1 & CRC & rs1800795 & C. $-174 G>C$ & rs1800470 & p.T29C & [57] & [71] & [158] \\
\hline IL6 & TGFB1 & GC & rs1800795 & C. $-174 G>C$ & rs1800470 & p.T29C & [57] & [71] & \\
\hline IL6 & TGFB1 & LC & rs1800795 & C. $-174 G>C$ & rs1800470 & p.T29C & [57] & [71] & \\
\hline IL6 & TGFB1 & $P C$ & rs1800795 & C. $-174 G>C$ & rs1800470 & p.T29C & [57] & [71] & [159] \\
\hline MMP2 & $E G F$ & LC & rs2438650 & c. $-1306 C>T$ & rs4444903 & c. $61 A>G$ & [160] & [161] & [162] \\
\hline MMP2 & $E G F$ & $B C$ & rs2438650 & c. $-1306 C>T$ & rs4444903 & c. $61 A>G$ & [160] & [161] & [163-165] \\
\hline MMP2 & $E G F$ & GC & rs2438650 & C. $-1306 C>T$ & rs4444903 & c. $61 A>G$ & [160] & [161] & \\
\hline VEGFA & $\operatorname{ILIB}$ & $B C$ & rs3025039 & c. $.936 C>T$ & rs114327 & NA & [166-169] & {$[170]$} & [171] \\
\hline VEGFA & $\operatorname{ILIB}$ & $B C$ & rs699947 & C. $-2578 \mathrm{C}>\mathrm{A}$ & rs1143634 & NA & [172] & {$[170]$} & [171] \\
\hline VEGFA & $I L 1 B$ & $B C$ & NA & NA & rs16944 & NA & NA & [170] & [171] \\
\hline VEGFA & $\| L 1 B$ & GC & rs3025039 & $c .936 C>T$ & rs3087258 & NA & [45] & [173] & \\
\hline VEGFA & $\| L 1 B$ & GC & rs699947 & c. $-2578 C>A$ & NA & IL1B-31-ami & [95] & [173] & \\
\hline MMP9 & $1 L 8$ & $B C$ & rs3918242 & c. $-1562 C>T$ & rs4073 & c. $-251 \mathrm{~A}>\mathrm{T}$ & [160] & [174] & [171] \\
\hline MMP9 & IL8 & CRC & rs3918242 & c. $-1562 C>T$ & rs4073 & c. $-251 \mathrm{~A}>\mathrm{T}$ & [160] & [174] & \\
\hline MMP9 & 128 & GC & rs3918242 & C. $-1562 C>T$ & rs4073 & C. $-251 \mathrm{~A}>\mathrm{T}$ & [160] & {$[175]$} & \\
\hline MMP9 & $1 L 8$ & LC & rs3918242 & c. $-1562 C>T$ & rs4073 & C. $-251 \mathrm{~A}>\mathrm{T}$ & [160] & [174] & \\
\hline MMP1 & MMP3 & $B C$ & rs1799750 & c. $-16071 \mathrm{G}>2 \mathrm{G}$ & rs3025058 & c. $-11715 \mathrm{~A}>6 \mathrm{~A}$ & [176] & [176] & \\
\hline MMP1 & MMP3 & CRC & rs1799750 & c. $-16071 \mathrm{G}>2 \mathrm{G}$ & rs3025058 & c. $-11715 \mathrm{~A}>6 \mathrm{~A}$ & [176] & [176] & \\
\hline MMP1 & MMP3 & HNC & rs1799750 & c. $-16071 \mathrm{G}>2 \mathrm{G}$ & rs3025058 & c. $-11715 \mathrm{~A}>6 \mathrm{~A}$ & [176] & {$[176]$} & \\
\hline MMP1 & MMP3 & LC & rs1799750 & c. $-16071 \mathrm{G}>2 \mathrm{G}$ & rs3025058 & c. $-11715 \mathrm{~A}>6 \mathrm{~A}$ & [176] & [176] & {$[177,178]$} \\
\hline MMP1 & MMP3 & OVCa & rs1799750 & c. $-16071 \mathrm{G}>2 \mathrm{G}$ & rs3025058 & c. $-11715 \mathrm{~A}>6 \mathrm{~A}$ & [176] & [176] & \\
\hline GSTP1 & GSTM1 & CRC & rs1695 & p.l105V & rs1065411 & GSTM1 present/null & [45] & [179] & \\
\hline GSTP1 & GSTM1 & $B C$ & rs1695 & p.1105V & rs1065412 & GSTM1 present/null & [180] & [181] & {$[182,183]$} \\
\hline GSTP1 & GSTM1 & OVCa & rs1695 & p.1105V & rs1065413 & GSTM1 present/null & [184] & [184] & \\
\hline GSTP1 & GSTM1 & UBC & rs1695 & p.1105V & rs1065414 & GSTM1 present/null & [185] & [186] & \\
\hline
\end{tabular}

These were identified in our meta-analysis. Their correlation with various cancer types is also shown. NA not available.

[188], malignant melanoma (MM) [189-192] and OVCa [193]. Additionally, regarding our further research on the interaction between IL6 and TGFB1 genes on mouse models, we have confirmed our initial results principally for BC [155-157] and PC [159] and have noticed associations with epithelial cancer [194], skin tumour [195], LC [196], OVCa and cervical cancer (CC) $[197,198]$ and HNSCC [199]. Second, we found that the interaction between $M M P-2$ and $E G F$ was associated with $\mathrm{LC}, \mathrm{BC}$ and GC (Table 4). Subsequently with a further literature search, we confirmed the association with $\mathrm{BC}$ osteolysis $[163,164]$ and also found new associations with EC [200], LC, RC and PC [162]. Furthermore, in some cases, we have observed the association of the aforementioned genes with OSCC [201]. In this study, EGF induced $M M P-1$ expression that is required for type I collagen degradation. In addition, $M M P-1$ is also associated with human papillomavirus [202] and BC [165].
Another interesting interaction that was revealed from our analysis was between the VEGFA and IL1B genes that were associated with BC and GC (Table 4). After proceeding with a further literature search, we have not found similar results - except from one report [171] - but we have identified additional associations with HNC, ALL, laryngeal carcinoma and MM [203-206]. For MMP-9 and IL8 interaction, there was no study confirming our initial results for $\mathrm{BC}, \mathrm{CRC}$ and $\mathrm{GC}$ on neither humans nor mouse models. We have observed though that there was evidence for an association with nasopharyngeal carcinoma [171], LC $[177,178]$ and UBC [207]. Similarly, we could not find any study that could support the interactions between $M M P-1$ and MMP-3 and GSTP1 with GSTM1, although two studies confirmed that GSTP1 and GSTM1 interactions could be associated with BC $[182,183]$ (Table 4).

Indications from further literature search on human models revealed associations for $M M P-1$ and $M M P-3$ with 


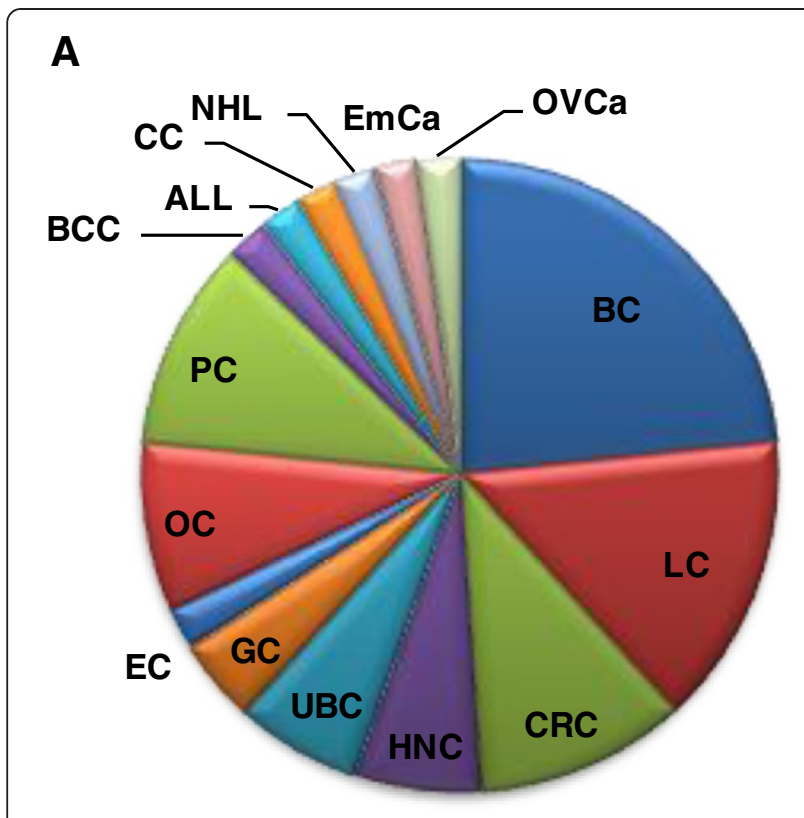

B

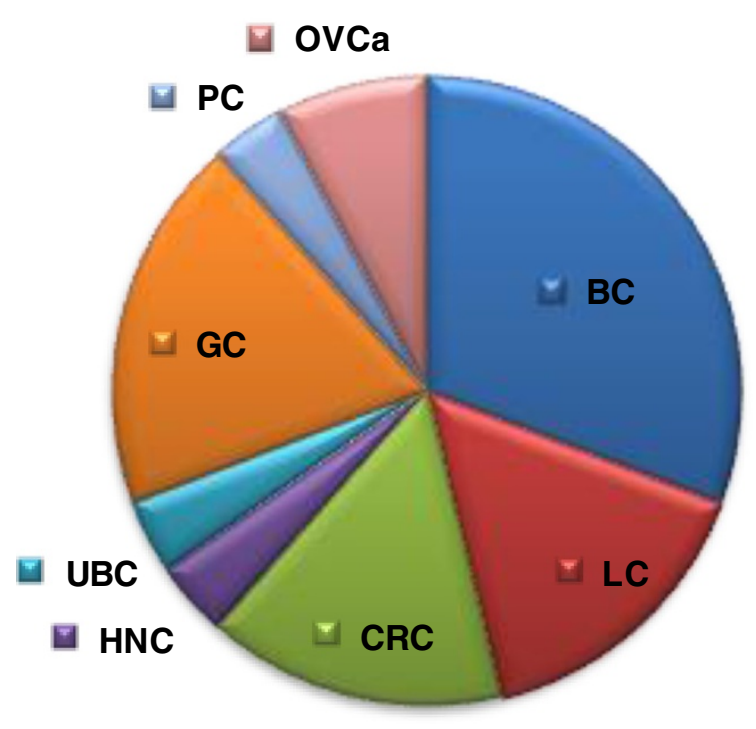

Figure 1 The distribution of various cancer types. According to (A) the number of SNPs per cancer type and (B) the number of genes or gene correlations per cancer type. By extrapolating the data in Tables 1, 2, 3 and 4, it seems that the number of genome variations and genes is profoundly bigger in $\mathrm{BC}$, probably indicating that this type of cancer is not a single disease but, most likely, a spectrum of related disease states.

types of cancer such as BCC, metatypical cancer of the skin [208], colorectal adenoma and RC [209,210], and for GSTP1 and GSTM1, endometrial cancer (EmCa) [211], LC [212], multiple myeloma (observed no significant association to prostatic adenoma and adenocarcinoma) [213], PC [133,214], ALL [215], chronic myeloid leukaemia [216] and PanC [217].
We have then attempted to depict the various types of cancers according to the number of SNPs and genes and/ or gene clusters found from our meta-analysis to be meaningfully associated with certain cancer types. Our data indicate that $\mathrm{BC}$ is correlated more often than the other types of cancer both with the number of SNPs (Figure 1A) as well as with the number of genes or gene clusters (Figure 1B). This observation underlies the heterogeneity of $\mathrm{BC}$, indicating that it is, most likely, not a single disease but a spectrum of related disease states.

\section{Conclusions}

In essence, our meta-analysis study generated clusters of genes and diseases, many of which proved to be independent of the criteria used, which suggests that these clusters are most likely biologically meaningful. Preliminary study of some clusters and of our results shows that indeed these genes interact. As regards the associations, with a further literature analysis on human and mouse models, we have also found meaningful gene associations related to other cancer types not previously reported in the literature, an observation that warrants further investigation.

\section{Additional file}

\section{Additional file 1: Genes and cancer types included in this meta-} analysis.

\section{Competing interests}

The authors declare that they have no competing interests.

\section{Authors' contributions}

ZL carried out the data collection, result analysis and participated in the manuscript preparation. EG participated in the manuscript preparation and data analysis. MF participated in the result and statistical analysis and manuscript revision. EK participated in the data collection and manuscript revision. JCN carried out the result and statistical analysis and participated in the manuscript preparation. HPK participated in the manuscript preparation. GPP participated in the design of the study, data analysis and manuscript preparation. CP conceived of the study, participated in its design and coordination as well as manuscript preparation. All authors read and approved for the final manuscript.

\section{Acknowledgements}

This study was conducted to fulfil the requirements of an undergraduate thesis, jointly with the Universities of Trieste, Italy and Patras, Greece. This work was partly funded by the University of Patras research budget and a European Commission grant (GEN2PHEN; FP7-200754) to GPP.

\section{Author details}

${ }^{1}$ Faculty of Mathematical, Physical and Natural Sciences, Department of Biological Sciences, University of Trieste, Trieste 34128, Italy. ${ }^{2}$ School of Health Sciences, Department of Pharmacy, University of Patras, University Campus, Rio, Patras 26504, Greece. ${ }^{3}$ Clinical Oncology Laboratory, Division of Oncology, Department of Medicine, University of Patras, Rio, Patras 26504, Greece. ${ }^{4}$ School of Computing and Information Systems, Faculty of Science, Engineering and Computing, Kingston University, London SW15 3DW, UK.

Received: 25 March 2013 Accepted: 1 May 2013

Published: 5 June 2013 


\section{References}

1. Lea IA, Jackson MA, Li X, Bailey S, Peddada SD, Dunnick JK: Genetic pathways and mutation profiles of human cancers: site- and exposurespecific patterns. Carcinogenesis 2007, 28(9):1851-1858.

2. Dutt $A$, Beroukhim R: Single nucleotide polymorphism array analysis of cancer. Curr Opin Oncol 2007, 19(1):43-49.

3. Chung CC, Chanock SJ: Current status of genome-wide association studies in cancer. Hum Genet 2011, 130(1):59-78.

4. Rae JM, Skaar TC, Hilsenbeck SG, Oesterreich S: The role of single nucleotide polymorphisms in breast cancer metastasis. Breast Cancer Res 2008, 10(1):301.

5. Teraoka SN, Bernstein JL, Reiner AS, Haile RW, Bernstein L, Lynch CF, Malone KE, Stovall M, Capanu M, Liang X, Smith SA, Mychaleckyj J, Hou X, Mellemkjaer L, Boice JD Jr, Siniard A, Duggan D, Thomas DC, WECARE Study Collaborative Group, Concannon P: Single nucleotide polymorphisms associated with risk for contralateral breast cancer in the women's environment, cancer, and radiation epidemiology (WECARE) study. Breast Cancer Res 2011, 13(6):R114.

6. Inaki K, Liu ET: Structural mutations in cancer: mechanistic and functional insights. Trends Genet 2012, 28(11):550-559.

7. You JS, Jones PA: Cancer genetics and epigenetics: two sides of the same coin? Cancer Cell 2012, 22(1):9-20.

8. Lopez-Lazaro M: A new view of carcinogenesis and an alternative approach to cancer therapy. Mol Med 2010, 16(3-4):144-153.

9. Rasmussen MD, Deshpande MS, Karypis G, Johnson J, Crow JA, Retzel EF: wCLUTO: a Web-enabled clustering toolkit. Plant Physiol 2003, 133(2):510-516.

10. Szklarczyk D, Franceschini A, Kuhn M, Simonovic M, Roth A, Minguez P, Doerks T, Stark M, Muller J, Bork P, Jensen LJ, von Mering C: The STRING database in 2011: functional interaction networks of proteins, globally integrated and scored. Nucleic Acids Res 2011, 39(Database issue):D561-D568.

11. Search Tool for the Retrieval of Interacting Genes/Proteins. www.string-db.org

12. Jiang $Z, L i C, X u Y, C$, Cai S, Wang X: Associations between XPD polymorphisms and risk of breast cancer: a meta-analysis. Breast Cancer Res Treat 2010, 123(1):203-212.

13. Qiu LX, Yao L, Zhang J, Zhu XD, Zhao XM, Xue K, Mao C, Chen B, Zhan P, Yuan H, Hu X-C: XPD Lys751Gln polymorphism and breast cancer susceptibility: a meta-analysis involving 28,709 subjects. Breast Cancer Res Treat 2010, 124(1):229-235.

14. Wang HC, Liu CS, Wang CH, Tsai RY, Tsai CW, Wang RF, Chang CH, Chen YS, Chiu CF, Bau DT, Huang CY: Significant association of XPD Asp312Asn polymorphism with breast cancer in Taiwanese patients. Chin J Physiol 2010, 53(2):130-135.

15. Han W, Kim KY, Yang SJ, Noh DY, Kang D, Kwack K: SNP-SNP interactions between DNA repair genes were associated with breast cancer risk in a Korean population. Cancer 2012, 118(3):594-602.

16. Hussien YM, Gharib AF, Awad HA, Karam RA, Elsawy WH: Impact of DNA repair genes polymorphism (XPD and XRCC1) on the risk of breast cancer in Egyptian female patients. Mol Biol Rep 2012, 39(2):1895-1901.

17. Yin J, Vogel U, Wang C, Liang D, Ma Y, Wang H, Yue L, Liu D, Ma J, Sun X: Hapmap-based evaluation of ERCC2, PPP1R13L, and ERCC1 and lung cancer risk in a Chinese population. Environ Mol Mutagen 2012. 53(3):239-245.

18. Yao L, Qiu LX, Yu L, Yang Z, Yu XJ, Zhong Y, Hu XC: The association between ERCC2 Asp312Asn polymorphism and breast cancer risk: a meta-analysis involving 22,766 subjects. Breast Cancer Res Treat 2010, 123(1):227-231.

19. Zhang J, Gu SY, Zhang P, Jia Z, Chang JH: ERCC2 Lys751Gln polymorphism is associated with lung cancer among Caucasians. Eur J Cancer 2010, 46(13):2479-2484.

20. Zhan P, Wang Q, Wei SZ, Wang J, Qian Q, Yu LK, Song Y: ERCC2/XPD Lys751GIn and Asp312Asn gene polymorphism and lung cancer risk: a meta-analysis involving 22 case-control studies. J Thorac Oncol 2010, 5(9):1337-1345.

21. Yin J, Vogel U, Ma Y, Qi R, Wang H, Yue L, Liang D, Wang C, Li X, Song T: HapMap-based study of a region encompassing ERCC1 and ERCC2 related to lung cancer susceptibility in a Chinese population. Mutat Res 2011, 713(1-2):1-7.

22. Christiani DC: ERCC2/XPD polymorphisms and lung cancer risk. J Thorac
Oncol 2011, 6(1):233. author reply 233-235

23. Zhang J, Qiu LX, Leaw SJ, Hu XC, Chang JH: The association between XPD Asp312Asn polymorphism and lung cancer risk: a meta-analysis including 16,949 subjects. Med Oncol 2011, 28(3):655-660.

24. Sergentanis TN, Economopoulos KP: Cyclin D1 G870A polymorphism and breast cancer risk: a meta-analysis comprising 9,911 cases and 11,171 controls. Mol Biol Rep 2011, 38(8):4955-4963.

25. Millar EK, Dean JL, McNeil CM, O'Toole SA, Henshall SM, Tran T, Lin J, Quong A, Comstock CE, Witkiewicz A, Musgrove EA, Rui H, Lemarchand L, Setiawan WW, Haiman CA, Knudsen KE, Sutherland RL, Knudsen ES: Cyclin D1b protein expression in breast cancer is independent of cyclin D1a and associated with poor disease outcome. Oncogene 2009, 28(15):1812-1820.

26. Miyashita H, Mori S, Tanda N, Nakayama K, Kanzaki A, Sato A, Morikawa H, Motegi K, Takebayashi Y, Fukumoto M: Loss of heterozygosity of nucleotide excision repair factors in sporadic oral squamous cell carcinoma using microdissected tissue. Oncol Rep 2001, 8(5):1133-1138.

27. Ghosh-Choudhury N, Ghosh-Choudhury G, Celeste A, Ghosh PM, Moyer M, Abboud SL, Kreisberg J: Bone morphogenetic protein-2 induces cyclin kinase inhibitor p21 and hypophosphorylation of retinoblastoma protein in estradiol-treated MCF-7 human breast cancer cells. Biochim Biophys Acta 2000, 1497(2):186-196.

28. Musgrove EA, Hui R, Sweeney K, Watts CK, Sutherland RL: Cyclins and breast cancer. J Mammary Gland Biol Neoplasia 1996, 1(2):153-162.

29. Sutherland RL, Hamilton JA, Sweeney KJ, Watts CK, Musgrove EA: Expression and regulation of cyclin genes in breast cancer. Acta Oncol 1995, 34(5):651-656.

30. Taneja P, Frazier DP, Kendig RD, Maglic D, Sugiyama T, Kai F, Taneja NK, Inoue $\mathrm{K}$ : MMTV mouse models and the diagnostic values of MMTV-like sequences in human breast cancer. Expert Rev Mol Diagn 2009, 9(5):423-440.

31. Yang C, lonescu-Tiba V, Burns K, Gadd M, Zukerberg L, Louis DN, Sgroi D, Schmidt EV: The role of the cyclin D1-dependent kinases in ErbB2mediated breast cancer. Am J Pathol 2004, 164(3):1031-1038.

32. Zhou GW, Hu J, Li Q: CYP2E1 Pstl/Rsal polymorphism and colorectal cancer risk: a meta-analysis. World J Gastroenterol 2010, 16(23):2949-2953.

33. Silva TD, Felipe AV, Pimenta CA, Barao K, Forones NM: CYP2E1 Rsal and 96-bp insertion genetic polymorphisms associated with risk for colorectal cancer. Genet Mol Res 2012, 11(3):3138-3145.

34. Sameer AS, Nissar S, Qadri Q, Alam S, Baba SM, Siddiqi MA: Role of CYP2E1 genotypes in susceptibility to colorectal cancer in the Kashmiri population. Hum Genomics 2011, 5(6):530-537.

35. Yang H, Zhou Y, Zhou Z, Liu J, Yuan X, Matsuo K, Takezaki T, Tajima K, Cao J: A novel polymorphism rs1329149 of CYP2E1 and a known polymorphism rs671 of ALDH2 of alcohol metabolizing enzymes are associated with colorectal cancer in a southwestern Chinese population. Cancer Epidemiol Biomarkers Prev 2009, 18(9):2522-2527.

36. Kury S, Buecher B, Robiou-du-Pont S, Scoul C, Sebille V, Colman H, Le Houerou C, Le Neel T, Bourdon J, Faroux R, Ollivry J, Lafraise B, Chupin LD, Bézieau S: Combinations of cytochrome P450 gene polymorphisms enhancing the risk for sporadic colorectal cancer related to red meat consumption. Cancer Epidemiol Biomarkers Prev 2007, 16(7):1460-1467.

37. Chen $\mathrm{K}$, Jin MJ, Fan $\mathrm{CH}$, Song L, Jiang QT, Yu WP, Ma XY, Yao KY: A case-control study on the association between genetic polymorphisms of metabolic enzymes and the risk of colorectal cancer. Zhonghua Liu Xing Bing Xue Za Zhi 2005, 26(9):659-664.

38. van der Logt EM, Bergevoet SM, Roelofs HM, Te Morsche RH, Dijk Y, Wobbes T, Nagengast FM, Peters WH: Role of epoxide hydrolase, NAD(P)H: quinone oxidoreductase, cytochrome P450 2E1 or alcohol dehydrogenase genotypes in susceptibility to colorectal cancer. Mutat Res 2006, 593(1-2):39-49.

39. Landi S, Gemignani F, Moreno V, Gioia-Patricola L, Chabrier A, Guino E, Navarro M, de Oca J, Capella G, Canzian F: A comprehensive analysis of phase I and phase II metabolism gene polymorphisms and risk of colorectal cancer. Pharmacogenet Genomics 2005, 15(8):535-546.

40. Cotterchio M, Boucher BA, Manno M, Gallinger S, Okey AB, Harper PA: Red meat intake, doneness, polymorphisms in genes that encode carcinogen-metabolizing enzymes, and colorectal cancer risk. Cancer Epidemiol Biomarkers Prev 2008, 17(11):3098-3107.

41. Chen J, Huang XF: The signal pathways in azoxymethane-induced colon cancer and preventive implications. Cancer Biol Ther 2009, 8(14):1313-1317. 
42. Tang K, Li Y, Zhang Z, Gu Y, Xiong Y, Feng G, He L, Qin S: The Pstl/Rsal and Dral polymorphisms of CYP2E1 and head and neck cancer risk: a metaanalysis based on 21 case-control studies. BMC Cancer 2010, 10:575.

43. Lu D, Yu X, Du Y: Meta-analyses of the effect of cytochrome P450 2E1 gene polymorphism on the risk of head and neck cancer. Mol Biol Rep 2011, 38(4):2409-2416.

44. Garcia SM, Curioni OA, de Carvalho MB, Gattas GJ: Polymorphisms in alcohol metabolizing genes and the risk of head and neck cancer in a Brazilian population. Alcohol Alcohol 2010, 45(1):6-12.

45. Economopoulos KP, Sergentanis TN: GSTM1, GSTT1, GSTP1, GSTA1 and colorectal cancer risk: a comprehensive meta-analysis. Eur J Cancer 2010, 46(9):1617-1631.

46. Ebrahimkhani S, Asgharian AM, Nourinaier B, Ebrahimkhani K, Vali N, Abbasi F, Zali MR: Association of GSTM1, GSTT1, GSTP1 and CYP2E1 single nucleotide polymorphisms with colorectal cancer in Iran. Pathol Oncol Res 2012, 18(3):651-656.

47. Sameer AS, Qadri Q, Siddiqi MA: GSTP1 I105V polymorphism and susceptibility to colorectal cancer in Kashmiri population. DNA Cell Biol 2012, 31(1):74-79.

48. Wang J, Joshi AD, Corral R, Siegmund KD, Marchand LL, Martinez ME, Haile RW, Ahnen DJ, Sandler RS, Lance P, Stern MC: Carcinogen metabolism genes, red meat and poultry intake, and colorectal cancer risk. Int J Cancer 2012, 130(8):1898-1907.

49. Sainz J, Rudolph A, Hein R, Hoffmeister M, Buch S, von Schonfels W, Hampe J, Schafmayer C, Volzke H, Frank B, Brenner H, Försti A, Hemminki K, Chang-Claude J: Association of genetic polymorphisms in ESR2, HSD17B1, ABCB1, and SHBG genes with colorectal cancer risk. Endocr Relat Cancer 2011, 18(2):265-276.

50. Jones BA, Christensen AR, Wise JP Sr, Yu H: Glutathione S-transferase polymorphisms and survival in African-American and white colorectal cancer patients. Cancer Epidemiol 2009, 33(3-4):249-256.

51. Skjelbred CF, Saebo M, Hjartaker A, Grotmol T, Hansteen IL, Tveit KM, Hoff G, Kure $\mathrm{EH}$ : Meat, vegetables and genetic polymorphisms and the risk of colorectal carcinomas and adenomas. BMC Cancer 2007, 7:228.

52. Talseth BA, Meldrum C, Suchy J, Kurzawski G, Lubinski J, Scott RJ: Genetic polymorphisms in xenobiotic clearance genes and their influence on disease expression in hereditary nonpolyposis colorectal cancer patients. Cancer Epidemiol Biomarkers Prev 2006, 15(11):2307-2310.

53. Romero RZ, Morales R, Garcia F, Huarriz M, Bandres E, De la Haba J, Gomez A, Aranda E, Garcia-Foncillas J: Potential application of GSTT1-null genotype in predicting toxicity associated to 5 -fluouracil irinotecan and leucovorin regimen in advanced stage colorectal cancer patients. Oncol Rep 2006, 16(3):497-503

54. Probst-Hensch NM, Sun CL, Van Den Berg D, Ceschi M, Koh WP, Yu MC: The effect of the cyclin D1 (CCND1) A870G polymorphism on colorectal cancer risk is modified by glutathione-S-transferase polymorphisms and isothiocyanate intake in the Singapore Chinese health study. Carcinogenesis 2006, 27(12):2475-2482.

55. Gaustadnes M, Orntoft TF, Jensen JL, Torring N: Validation of the use of DNA pools and primer extension in association studies of sporadic colorectal cancer for selection of candidate SNPs. Hum Mutat 2006, 27(2):187-194.

56. Yu KD, Di GH, Fan L, Chen AX, Yang C, Shao ZM: Lack of an association between a functional polymorphism in the interleukin- 6 gene promote and breast cancer risk: a meta-analysis involving 25,703 subjects. Breast Cancer Res Treat 2010, 122(2):483-488.

57. Xu B, Niu XB, Wang ZD, Cheng W, Tong N, Mi YY, Min ZC, Tao J, Li PC, Zhang W, Wu HF, Zhang ZD, Wang ZJ, Hua LX, Feng NH, Wang XR: IL-6-174G >C polymorphism and cancer risk: a meta-analysis involving 29,377 cases and 37,739 controls. Mol Biol Rep 2011, 38(4):2589-2596.

58. Dong X, Wu J, Liang P, Li J, Yuan L, Liu X: Methylenetetrahydrofolate reductase C677T and $\mathrm{A} 1298 \mathrm{C}$ polymorphisms and gastric cancer: a meta-analysis. Arch Med Res 2010, 41(2):125-133.

59. Wang Z, Chen JQ, Liu JL, Qin XG, Huang Y: Polymorphisms in ERCC1, GSTs, TS and MTHFR predict clinical outcomes of gastric cancer patients treated with platinum/5-Fu-based chemotherapy: a systematic review. BMC Gastroenterol 2012, 12:137.

60. Balassiano K, Lima S, Jenab M, Overvad K, Tjonneland A, Boutron-Ruault MC, Clavel-Chapelon F, Canzian F, Kaaks R, Boeing H, Meidtner K, Trichopoulou A, Laglou P, Vineis P, Panico S, Palli D, Grioni S, Tumino R, Lund E,
Bueno-de-Mesquita HB, Numans ME, Peeters PH, Ramon Quirós J, Sánchez MJ, Navarro C, Ardanaz E, Dorronsoro M, Hallmans G, Stenling R, et al: Aberrant DNA methylation of cancer-associated genes in gastric cancer in the European Prospective Investigation into Cancer and Nutrition (EPIC-EURGAST). Cancer Lett 2011, 311(1):85-95.

61. Qi X, Ma X, Yang X, Fan L, Zhang Y, Zhang F, Chen L, Zhou Y, Jiang J: Methylenetetrahydrofolate reductase polymorphisms and breast cancer risk: a meta-analysis from 41 studies with 16,480 cases and 22,388 controls. Breast Cancer Res Treat 2010, 123(2):499-506.

62. Qiu LX, Zhang J, Li WH, Zhang QL, Yu H, Wang BY, Wang LP, Wang JL, Wang HJ, Liu XJ, Luo ZG, Wu XH: Lack of association between methylenetetrahydrofolate reductase gene $\mathrm{A} 1298 \mathrm{C}$ polymorphism and breast cancer susceptibility. Mol Biol Rep 2011, 38(4):2295-2299.

63. Perel'muter VM, Zav'ialova MV, Vtorushin SV, Slonimskaia EM, Kritskaia NG, Garbukov E, Litviakov NV, Stakheeva MN, Babyshkina NN, Malinovskaia EA Denisov EV, Grigor'eva ES, Nazarenko MS, Sennikov SV, Goreva EP, Kozlov VA, Voevoda MI, Maksimov VN, Beliavskaia VA, Cherdyntseva NV: Genetic and clinical and pathological characteristics of breast cancer in premenopausal and postmenopausal women. Adv Gerontol 2008, 21(4):643-653.

64. Stevens VL, McCullough ML, Pavluck AL, Talbot JT, Feigelson HS, Thun MJ, Calle EE: Association of polymorphisms in one-carbon metabolism genes and postmenopausal breast cancer incidence. Cancer Epidemiol Biomarkers Prev 2007, 16(6):1140-1147.

65. Qiu LX, Mao C, Yao L, Yu KD, Zhan P, Chen B, Liu HG, Yuan H, Zhang J, Xue K, Hu XC: XRCC3 5'-UTR and IVS5-14 polymorphisms and breast cancer susceptibility: a meta-analysis. Breast Cancer Res Treat 2010, 122(2):489-493

66. Chen Y, Pei J: Possible risk modifications in the association between MnSOD Ala-9Val polymorphism and breast cancer risk: subgroup analysis and evidence-based sample size calculation for a future trial. Breast Cancer Res Treat 2011, 125(2):495-504.

67. Qi X, Zhang F, Yang X, Fan L, Zhang Y, Chen L, Zhou Y, Chen X, Zhong L, Jiang J: Transforming growth factor-beta1 polymorphisms and breast cancer risk: a meta-analysis based on 27 case-control studies. Breast Cancer Res Treat 2010, 122(1):273-279.

68. Huang Y, Hao Y, Li B, Xie J, Qian J, Chao C, Yu L: Lack of significant association between TGF-beta1-590C/T polymorphism and breast cancer risk: a meta-analysis. Med Oncol 2011, 28(2):424-428.

69. Woo SU, Park KH, Woo OH, Yang DS, Kim AR, Lee ES, Lee JB, Kim YH, Kim JS, Seo $J \mathrm{H}$ : Association of a TGF-beta1 gene $-509 \mathrm{C} / \mathrm{T}$ polymorphism with breast cancer risk: a meta-analysis. Breast Cancer Res Treat 2010, 124(2):481-485.

70. Gu D, Zhuang L, Huang H, Cao P, Wang D, Tang J, Chen J: TGFB1 T29C polymorphism and breast cancer risk: a meta-analysis based on 10,417 cases and 11,455 controls. Breast Cancer Res Treat 2010, 123(3):857-861.

71. Wei BB, Xi B, Wang R, Bai JM, Chang JK, Zhang YY, Yoneda R, Su JT, Hua LX: TGFbeta1 T29C polymorphism and cancer risk: a meta-analysis based on 40 case-control studies. Cancer Genet Cytogenet 2010, 196(1):68-75.

72. Ma X, Chen C, Xiong H, Li Y: Transforming growth factorbeta1 L10P variant plays an active role on the breast cancer susceptibility in Caucasian: evidence from 10,392 cases and 11,697 controls. Breast Cancer Res Treat 2010, 124(2):453-457.

73. Huang Y, Li B, Qian J, Xie J, Yu L: TGF-beta1 29T/C polymorphism and breast cancer risk: a meta-analysis involving 25,996 subjects. Breast Cancer Res Treat 2010, 123(3):863-868.

74. Qiu LX, Yao L, Mao C, Chen B, Zhan P, Xue K, Zhang J, Yuan H, Hu XC: TGFB1 L10P polymorphism is associated with breast cancer susceptibility: evidence from a meta-analysis involving 47,817 subjects. Breast Cancer Res Treat 2010, 123(2):563-567.

75. Radisky DC, Hartmann LC: Mammary involution and breast cancer risk: transgenic models and clinical studies. J Mammary Gland Biol Neoplasia 2009, 14(2):181-191.

76. Stuelten $\mathrm{CH}$, Busch Jl, Tang B, Flanders KC, Oshima A, Sutton E, Karpova TS, Roberts AB, Wakefield LM, Niederhuber JE: Transient tumor-fibroblast interactions increase tumor cell malignancy by a TGF-Beta mediated mechanism in a mouse xenograft model of breast cancer. PLoS One 2010, 5(3):e9832.

77. Zheng W: Genetic polymorphisms in the transforming growth factorbeta signaling pathways and breast cancer risk and survival. Methods $\mathrm{Mol}$ Biol 2009, 472:265-277 
78. Hu Z, Li X, Qu X, He Y, Ring BZ, Song E, Su L: Intron 316 bp duplication polymorphism of TP53 contributes to cancer susceptibility: a meta-analysis. Carcinogenesis 2010, 31(4):643-647.

79. Ma Y, Yang J, Liu Z, Zhang P, Yang Z, Wang Y, Qin H: No significant association between the TP53 codon 72 polymorphism and breast cancer risk: a meta-analysis of 21 studies involving 24,063 subjects. Breast Cancer Res Treat 2011, 125(1):201-205.

80. Chunder N, Mandal S, Roy A, Roychoudhury S, Panda CK: Differential association of BRCA1 and BRCA2 genes with some breast cancer-associated genes in early and late onset breast tumors. Ann Surg Oncol 2004, 11(12):1045-1055.

81. Rebbeck TR: Inherited genetic predisposition in breast cancer. A population-based perspective. Cancer 1999, 86(11 Suppl):2493-2501.

82. Rossner P Jr, Gammon MD, Zhang YJ, Terry MB, Hibshoosh H, Memeo L, Mansukhani M, Long CM, Garbowski G, Agrawal M, Agrawal M, Kalra TS, Gaudet MM, Teitelbaum SL, Neugut Al, Santella RM: Mutations in p53, p53 protein overexpression and breast cancer survival. J Cell Mol Med 2009, 13(9B):3847-3857.

83. Nkhata KJ, Ray A, Schuster TF, Grossmann ME, Cleary MP: Effects of adiponectin and leptin co-treatment on human breast cancer cell growth. Oncol Rep 2009, 21(6):1611-1619.

84. Palanca Suela S, Esteban Cardenosa E, Barragan Gonzalez E, de Juan Jimenez I, Chirivella Gonzalez I, Segura Huerta A, Guillen Ponce C, Montalar Salcedo J, Martinez de Duenas E, Castel Sanchez V, Bolufer Gilabert P, Group for Assessment of Hereditary Cancer of Valencia Community: CASP8 D302H polymorphism delays the age of onset of breast cancer in BRCA1 and BRCA2 carriers. Breast Cancer Res Treat 2010, 119(1):87-93.

85. Fanale D, Amodeo V, Corsini LR, Rizzo S, Bazan V, Russo A: Breast cancer genome-wide association studies: there is strength in numbers. Oncogene 2012, 31(17):2121-2128.

86. Cherdyntseva NV, Denisov EV, Litviakov NV, Maksimov VN, Malinovskaya EA, Babyshkina NN, Slonimskaya EM, Voevoda MI, Choinzonov EL: Crosstalk between the FGFR2 and TP53 genes in breast cancer: data from an association study and epistatic interaction analysis. DNA Cell Biol 2012, 31(3):306-316.

87. Lo Nigro C, Vivenza D, Monteverde M, Lattanzio L, Gojis O, Garrone O, Comino A, Merlano M, Quinlan PR, Syed N, Purdie CA, Thompson A, Palmieri C, Crook T: High frequency of complex TP53 mutations in CNS metastases from breast cancer. Br J Cancer 2012, 106(2):397-404.

88. Mathoulin-Portier MP, Viens P, Cowen D, Bertucci F, Houvenaeghel G, Geneix J, Puig B, Bardou VJ, Jacquemier J: Prognostic value of simultaneous expression of p21 and $\mathrm{mdm} 2$ in breast carcinomas treated by adjuvant chemotherapy with antracyclin. Oncol Rep 2000, 7(3):675-680.

89. Blackburn AC, Jerry DJ: Knockout and transgenic mice of Trp53: what have we learned about p53 in breast cancer? Breast Cancer Res 2002, 4(3):101-111.

90. Bennett CN, Green JE: Genomic analyses as a guide to target identification and preclinical testing of mouse models of breast cancer. Toxicol Pathol 2010, 38(1):88-95.

91. Girardini JE, Napoli M, Piazza S, Rustighi A, Marotta C, Radaelli E, Capaci V, Jordan L, Quinlan P, Thompson A, Mano M, Rosato A, Crook T, Scanziani E, Means AR, Lozano G, Schneider C, Del Sal G: A Pin1/mutant p53 axis promotes aggressiveness in breast cancer. Cancer Cell 2011, 20(1):79-91.

92. Alsner J, Jensen V, Kyndi M, Offersen BV, Vu P, Borresen-Dale AL, Overgaard J: A comparison between $\mathrm{p} 53$ accumulation determined by immunohistochemistry and TP53 mutations as prognostic variables in tumours from breast cancer patients. Acta Oncol 2008, 47(4):600-607.

93. Bourdon JC, Khoury MP, Diot A, Baker L, Fernandes K, Aoubala M, Quinlan P, Purdie CA, Jordan LB, Prats AC, Lane DP, Thompson AM: p53 mutant breast cancer patients expressing p53gamma have as good a prognosis as wild-type p53 breast cancer patients. Breast Cancer Res 2011, 13(1):R7.

94. Besaratinia A, Pfeifer GP: Applications of the human p53 knock-in (Hupki) mouse model for human carcinogen testing. FASEB J 2010, 24(8):2612-2619.

95. Jiang DK, Ren WH, Yao L, Wang WZ, Peng B, Yu L: Meta-analysis of association between TP53 Arg72Pro polymorphism and bladder cancer risk. Urology 2010, 76(3):765-767. e761.

96. Burger M, Burger SJ, Denzinger S, Wild PJ, Wieland WF, Blaszyk H, Obermann EC, Stoehr R, Hartmann A: Elevated microsatellite instability at selected tetranucleotide repeats does not correlate with clinicopathologic features of bladder cancer. Eur Urol 2006, 50(4):770-775. discussion 776.

97. Zuiverloon TC, Abas CS, van der Keur KA, Vermeij M, Tjin SS, van Tilborg AG, Busstra M, Zwarthoff EC: In-depth investigation of the molecular pathogenesis of bladder cancer in a unique 26-year old patient with extensive multifocal disease: a case report. BMC Urol 2010, 10:5.

98. Kompier LC, van Tilborg AA, Zwarthoff EC: Bladder cancer: novel molecular characteristics, diagnostic, and therapeutic implications. Urol Oncol 2010, 28(1):91-96.

99. Jarmalaite S, Andrekute R, Scesnaite A, Suziedelis K, Husgafvel-Pursiainen K, Jankevicius F: Promoter hypermethylation in tumour suppressor genes and response to interleukin-2 treatment in bladder cancer: a pilot study. J Cancer Res Clin Oncol 2010, 136(6):847-854.

100. Lin HY, Huang CH, Yu TJ, Wu WJ, Yang MC, Lung FW: p53 codon 72 polymorphism as a progression index for bladder cancer. Oncol Rep 2012, 27(4):1193-1199.

101. Dahabreh IJ, Linardou H, Bouzika P, Varvarigou V, Murray S: TP53 Arg72Pro polymorphism and colorectal cancer risk: a systematic review and metaanalysis. Cancer Epidemiol Biomarkers Prev 2010, 19(7):1840-1847.

102. Economopoulos KP, Sergentanis TN, Zagouri F, Zografos GC: Association between p53 Arg72Pro polymorphism and colorectal cancer risk: a meta-analysis. Onkologie 2010, 33(12):666-674

103. Wang JJ, Zheng Y, Sun L, Wang L, Yu PB, Dong JH, Zhang L, Xu J, Shi W, Ren YC: TP53 codon 72 polymorphism and colorectal cancer susceptibility: a meta-analysis. Mol Biol Rep 2011, 38(8):4847-4853.

104. Goodman JE, Mechanic LE, Luke BT, Ambs S, Chanock S, Harris CC: Exploring SNP-SNP interactions and colon cancer risk using polymorphism interaction analysis. Int J Cancer 2006, 118(7):1790-1797.

105. Zhang Y, Liu L, Tang Y, Chen C, Wang Q, Xu J, Yang C, Miao X, Wei S, Chen J, Nie S: Polymorphisms in TP53 and MDM2 contribute to higher risk of colorectal cancer in Chinese population: a hospital-based, casecontrol study. Mol Biol Rep 2012, 39(10):9661-9668.

106. Lopez I, PO L, Tucci P, Alvarez-Valin F, AC R, Marin M: Different mutation profiles associated to P53 accumulation in colorectal cancer. Gene 2012, 499(1):81-87.

107. Kanaan Z, Rai SN, Eichenberger MR, Barnes C, Dworkin AM, Weller C, Cohen E, Roberts H, Keskey B, Petras RE, Crawford NP, Galandiuk S: Differential microRNA expression tracks neoplastic progression in inflammatory bowel disease-associated colorectal cancer. Hum Mutat 2012, 33(3):551-560.

108. Aizat AA, Shahpudin SN, Mustapha MA, Zakaria Z, Sidek AS, Abu Hassan MR, Ankathil R: Association of Arg72Pro of P53 polymorphism with colorectal cancer susceptibility risk in Malaysian population. Asian Pac J Cancer Prev 2011, 12(11):2909-2913.

109. Wang B, Wang D, Zhang D, Li A, Liu D, Liu H, Jin H: Pro variant of TP53 Arg72Pro contributes to esophageal squamous cell carcinoma risk: evidence from a meta-analysis. Eur J Cancer Prev 2010, 19(4):299-307.

110. Zhao Y, Wang F, Shan S, Qiu X, Li X, Jiao F, Wang J, Du Y: Genetic polymorphism of $\mathrm{p} 53$, but not GSTP1, is association with susceptibility to esophageal cancer risk - a meta-analysis. Int J Med Sci 2010, 7(5):300-308.

111. Bashash M, Yavari P, Hislop TG, Shah A, Sadjadi A, Babaei M, Le N, Brooks-Wilson A, Malekzadeh R, Bajdik C: Comparison of two diverse populations, British Columbia, Canada, and Ardabil, Iran, indicates several variables associated with gastric and esophageal cancer survival. J Gastrointest Cancer 2011, 42(1):40-45.

112. Duenas M, Santos M, Aranda JF, Bielza C, Martinez-Cruz AB, Lorz C, Taron M, Ciruelos EM, Rodriguez-Peralto JL, Martin M, Larrañaga P, Dahabreh J, Stathopoulos GP, Rosell R, Paramio JM, García-Escudero R: Mouse p53deficient cancer models as platforms for obtaining genomic predictors of human cancer clinical outcomes. PLoS One 2012, 7(8):e42494.

113. Perez-Morales R, Mendez-Ramirez I, Castro-Hernandez C, Martinez-Ramirez OC, Gonsebatt ME, Rubio J: Polymorphisms associated with the risk of lung cancer in a healthy Mexican Mestizo population: application of the additive model for cancer. Genet Mol Biol 2011, 34(4):546-552.

114. Deeb KK, Michalowska AM, Yoon CY, Krummey SM, Hoenerhoff MJ, Kavanaugh C, Li MC, Demayo FJ, Linnoila I, Deng CX, Lee EY, Medina D, Shih $\mathrm{JH}$, Green JE: Identification of an integrated SV40 T/t-antigen cancer signature in aggressive human breast, prostate, and lung carcinomas with poor prognosis. Cancer Res 2007, 67(17):8065-8080. 
115. Campling BG, el-Deiry WS: Clinical implications of p53 mutations in lung cancer. Methods Mol Med 2003, 75:53-77.

116. Meylan E, Dooley AL, Feldser DM, Shen L, Turk E, Ouyang C, Jacks T: Requirement for NF-kappaB signalling in a mouse model of lung adenocarcinoma. Nature 2009, 462(7269):104-107.

117. Fujiwara T, Cai DW, Georges RN, Mukhopadhyay T, Grimm EA, Roth JA: Therapeutic effect of a retroviral wild-type p53 expression vector in an orthotopic lung cancer model. J Natl Cancer Inst 1994, 86(19):1458-1462.

118. Jiang DK, Yao L, Ren WH, Wang WZ, Peng B, Yu L: TP53 Arg72Pro polymorphism and endometrial cancer risk: a meta-analysis. Med Oncol 2011, 28(4):1129-1135

119. Chen MB, Li C, Shen WX, Guo YJ, Shen W, Lu PH: Association of a LSP1 gene rs3817198T>C polymorphism with breast cancer risk: evidence from 33,920 cases and 35,671 controls. Mol Biol Rep 2011, 38(7):4687-4695

120. Bachelder RE, Crago A, Chung J, Wendt MA, Shaw LM, Robinson G, Mercurio AM: Vascular endothelial growth factor is an autocrine survival factor for neuropilin-expressing breast carcinoma cells. Cancer Res 2001, 61(15):5736-5740.

121. Eriksson L, Ahluwalia M, Spiewak J, Lee G, Sarma DS, Roomi MJ, Farber E: Distinctive biochemical pattern associated with resistance of hepatocytes in hepatocyte nodules during liver carcinogenesis. Environ Health Perspect 1983, 49:171-174.

122. Volm M, Koomagi R, Rittgen W: Clinical implications of cyclins, cyclindependent kinases, RB and E2F1 in squamous-cell lung carcinoma. Int J Cancer 1998, 79(3):294-299.

123. Anayama T, Furihata M, Takeuchi T, Sonobe $H$, Sasaguri S, Matsumoto M, Ohtsuki Y: Insufficient effect of p27(KIP1) to inhibit cyclin D1 in human esophageal cancer in vitro. Int J Oncol 2001, 18(1):151-155.

124. Buschges R, Weber RG, Actor B, Lichter P, Collins VP, Reifenberger G: Amplification and expression of cyclin D genes (CCND1, CCND2 and CCND3) in human malignant gliomas. Brain Pathol 1999, 9(3):435-442. discussion 432-433.

125. Comstock CE, Augello MA, Benito RP, Karch J, Tran TH, Utama FE, Tindall EA, Wang Y, Burd CJ, Groh EM, Hoang HN, Giles GG, Severi G, Hayes VM, Henderson BE, Le Marchand L, Kolonel LN, Haiman CA, Baffa R, Gomella LG, Knudsen ES, Rui H, Henshall SM, Sutherland RL, Knudsen KE: Cyclin D1 splice variants: polymorphism, risk, and isoform-specific regulation in prostate cancer. Clin Cancer Res 2009, 15(17):5338-5349.

126. Murata $M$, Watanabe $M$, Yamanaka M, Kubota $Y$, Ito H, Nagao M, Katoh T, Kamataki T, Kawamura J, Yatani R, Shiraishi T: Genetic polymorphisms in cytochrome P450 (CYP) 1A1, CYP1A2, CYP2E1, glutathione S-transferase (GST) M1 and GSTT1 and susceptibility to prostate cancer in the Japanese population. Cancer Lett 2001, 165(2):171-177

127. Uematsu F: Genetic polymorphisms of drug-metabolizing enzymes and susceptibility to lung cancer-relevance to smoking. Nihon Rinsho 1996, 54(2):513-517

128. Murray Gl, Taylor VE, McKay JA, Weaver RJ, Ewen SW, Melvin WT, Burke MD Expression of xenobiotic metabolizing enzymes in tumours of the urinary bladder. Int J Exp Pathol 1995, 76(4):271-276.

129. Hu YY, Yuan $H$, Jiang GB, Chen N, Wen L, Leng WD, Zeng XT, Niu YM: Associations between XPD Asp312Asn polymorphism and risk of head and neck cancer: a meta-analysis based on 7,122 subjects. PLoS One 2012, 7(4):e35220

130. Yuan H, Niu YM, Wang RX, Li HZ, Chen N: Association between XPD Lys751GIn polymorphism and risk of head and neck cancer: a meta-analysis. Genet Mol Res 2011, 10(4):3356-3364.

131. Kumar A, Pant MC, Singh HS, Khandelwal S: Associated risk of XRCC1 and XPD cross talk and life style factors in progression of head and neck cancer in north Indian population. Mutat Res 2012, 729(1-2):24-34.

132. Clapper ML: Genetic polymorphism and cancer risk. Curr Oncol Rep 2000, 2(3):251-256.

133. Likhin FA, Bartnovskii AE, Vdovichenko KK, Abramov AA, Belokhvostov AS: Characteristics of methyl-specific PCR-test of glutathione-S-transferase P1 gene in plasm DNA and cellular urinary precipitate for differential diagnosis of prostatic adenoma and adenocarcinoma. Urologiia 2005, 4:12-15.

134. Zhang Z, Liu W, Jia X, Gao Y, Hemminki K, Lindholm B: Use of pyrosequencing to detect clinically relevant polymorphisms of genes in basal cell carcinoma. Clin Chim Acta 2004, 342(1-2):137-143.
135. Krajinovic M, Lemieux-Blanchard E, Chiasson S, Primeau M, Costea I, Moghrabi A: Role of polymorphisms in MTHFR and MTHFD1 genes in the outcome of childhood acute lymphoblastic leukemia. Pharmacogenomics J 2004, 4(1):66-72

136. Petra BG, Janez J, Vita D: Gene-gene interactions in the folate metabolic pathway influence the risk for acute lymphoblastic leukemia in children. Leuk Lymphoma 2007, 48(4):786-792.

137. Matakidou A, El Galta R, Rudd MF, Webb EL, Bridle H, Eisen T, Houlston RS: Prognostic significance of folate metabolism polymorphisms for lung cancer. Br J Cancer 2007, 97(2):247-252.

138. Moore LE, Malats N, Rothman N, Real FX, Kogevinas M, Karami S, Garcia-Closas R, Silverman D, Chanock S, Welch R, Tardón A, Serra C, Carrato A, Dosemeci M, García-Closas M: Polymorphisms in one-carbon metabolism and trans-sulfuration pathway genes and susceptibility to bladder cancer. Int J Cancer 2007, 120(11):2452-2458.

139. Curtin K, Slattery ML, Ulrich CM, Bigler J, Levin TR, Wolff RK, Albertsen H, Potter JD, Samowitz WS: Genetic polymorphisms in one-carbon metabolism: associations with CpG island methylator phenotype (CIMP) in colon cancer and the modifying effects of diet. Carcinogenesis 2007 28(8):1672-1679.

140. Weiner AS, Beresina OV, Voronina EN, Voropaeva EN, Boyarskih UA Pospelova TI, Filipenko ML: Polymorphisms in folate-metabolizing genes and risk of non-Hodgkin's lymphoma. Leuk Res 2011, 35(4):508-515.

141. Lee KM, Lan Q, Kricker A, Purdue MP, Grulich AE, Vajdic CM, Turner J, Whitby D, Kang D, Chanock S, Rothman N, Armstrong BK: One-carbon metabolism gene polymorphisms and risk of non-Hodgkin lymphoma in Australia. Hum Genet 2007, 122(5):525-533.

142. Suzuki T, Matsuo K, Hasegawa Y, Hiraki A, Wakai K, Hirose K, Saito T, Sato S, Ueda R, Tajima K: One-carbon metabolism-related gene polymorphisms and risk of head and neck squamous cell carcinoma: case-control study. Cancer Sci 2007, 98(9):1439-1446.

143. Kim SH, Lee SH, Choi YL, Wang LH, Park CK, Shin YK: Extensive alteration in the expression profiles of TGFB pathway signaling components and TP53 is observed along the gastric dysplasia-carcinoma sequence. Histo Histopathol 2008, 23(12):1439-1452.

144. Gemma A, Uematsu K, Hagiwara K, Takenoshita S, Kudoh S: Mechanism of resistance to growth inhibition by transforming growth factor-beta 1 (TGF-beta 1) in primary lung cancer and new molecular targets in therapy. Gan To Kagaku Ryoho 2000, 27(8):1253-1259.

145. Jonson T, Albrechtsson E, Axelson J, Heidenblad M, Gorunova L, Johansson $B$, Hoglund M: Altered expression of TGFB receptors and mitogenic effects of TGFB in pancreatic carcinomas. Int J Oncol 2001, 19(1):71-81.

146. Franzen $\mathrm{P}$, Ichijo $H$, Miyazono K: Different signals mediate transforming growth factor-beta 1-induced growth inhibition and extracellular matrix production in prostatic carcinoma cells. Exp Cell Res 1993, 207(1):1-7.

147. Maggio-Price L, Treuting P, Bielefeldt-Ohmann H, Seamons A, Drivdahl R, Zeng W, Lai L, Huycke M, Phelps S, Brabb T, Iritani BM: Bacterial infection of Smad3/Rag2 double-null mice with transforming growth factor-beta dysregulation as a model for studying inflammation-associated colon cancer. Am J Pathol 2009, 174(1):317-329.

148. Hirshfield KM, Rebbeck TR, Levine AJ: Germline mutations and polymorphisms in the origins of cancers in women. J Oncol 2010, 2010:297671.

149. Volate SR, Kawasaki BT, Hurt EM, Milner JA, Kim YS, White J, Farrar WL: Gossypol induces apoptosis by activating p53 in prostate cancer cells and prostate tumor-initiating cells. Mol Cancer Ther 2010, 9(2):461-470.

150. Bernardini MQ, Baba T, Lee PS, Barnett JC, Sfakianos GP, Secord AA, Murphy SK, Iversen E, Marks JR, Berchuck A: Expression signatures of TP53 mutations in serous ovarian cancers. BMC Cancer 2010, 10:237.

151. Shimada S, Mimata A, Sekine M, Mogushi K, Akiyama Y, Fukamachi H, Jonkers J, Tanaka H, Eishi Y, Yuasa Y: Synergistic tumour suppressor activity of E-cadherin and p53 in a conditional mouse model for metastatic diffuse-type gastric cancer. Gut 2012, 61(3):344-353.

152. Sano D, Xie TX, Ow TJ, Zhao M, Pickering CR, Zhou G, Sandulache VC, Wheeler DA, Gibbs RA, Caulin C, Myers JN: Disruptive TP53 mutation is associated with aggressive disease characteristics in an orthotopic murine model of oral tongue cancer. Clin Cancer Res 2011, 17(21):6658-6670.

153. Furth PA, Cabrera MC, Diaz-Cruz ES, Millman S, Nakles RE: Assessing estrogen signaling aberrations in breast cancer risk using genetically engineered mouse models. Ann N Y Acad Sci 2011, 1229:147-155. 
154. de Jonge $\mathrm{R}$, Hooijberg $J H$, van Zelst BD, Jansen $\mathrm{G}$, van Zantwijk $\mathrm{CH}$, Kaspers GJ, Peters GJ, Ravindranath Y, Pieters R, Lindemans J: Effect of polymorphisms in folate-related genes on in vitro methotrexate sensitivity in pediatric acute lymphoblastic leukemia. Blood 2005, 106(2):717-720.

155. Durfort T, Tkach M, Meschaninova MI, Rivas MA, Elizalde PV, Venyaminova AG, Schillaci R, Francois JC: Small interfering RNA targeted to IGF-IR delays tumor growth and induces proinflammatory cytokines in a mouse breast cancer model. PLoS One 2012, 7(1):e29213.

156. Calogero RA, Cordero F, Forni G, Cavallo F: Inflammation and breast cancer. Inflammatory component of mammary carcinogenesis in ErbB2 transgenic mice. Breast Cancer Res 2007, 9(4):211.

157. Schiff R, Osborne CK: Endocrinology and hormone therapy in breast cancer: new insight into estrogen receptor-alpha function and its implication for endocrine therapy resistance in breast cancer. Breast Cancer Res 2005, 7(5):205-211.

158. Lahm H, Petral-Malec D, Yilmaz-Ceyhan A, Fischer JR, Lorenzoni M, Givel JC, Odartchenko N: Growth stimulation of a human colorectal carcinoma cell line by interleukin- 1 and -6 and antagonistic effects of transforming growth factor beta 1. Eur J Cancer 1992, 28A(11):1894-1899.

159. Yu C, Yao Z, Jiang Y, Keller ET: Prostate cancer stem cell biology. Minerva Urol Nefrol 2012, 64(1):19-33.

160. Peng B, Cao L, Ma X, Wang W, Wang D, Yu L: Meta-analysis of association between matrix metalloproteinases 2, 7 and 9 promoter polymorphisms and cancer risk. Mutagenesis 2010, 25(4):371-379.

161. Zhang YM, Cao C, Liang K: Genetic polymorphism of epidermal growth factor $61 \mathrm{~A}>\mathrm{G}$ and cancer risk: a meta-analysis. Cancer Epidemio/ 2010, 34(2):150-156.

162. Willmarth NE, Ethier SP: Amphiregulin as a novel target for breast cancer therapy. J Mammary Gland Biol Neoplasia 2008, 13(2):171-179.

163. Guise TA: Breaking down bone: new insight into site-specific mechanisms of breast cancer osteolysis mediated by metalloproteinases. Genes Dev 2009, 23(18):2117-2123.

164. Lacroix M, Body JJ: Regulation of c-fos and c-jun expression by calcitonin in human breast cancer cells. Calcif Tissue Int 1997, 60(6):513-519.

165. Chen MB, Wu XY, Shen W, Wei MX, Li C, Cai B, Tao GQ, Lu PH: Association between polymorphisms of trinucleotide repeat containing 9 gene and breast cancer risk: evidence from 62,005 subjects. Breast Cancer Res Treat 2011, 126(1):177-183.

166. Gu D, Wang M: VEGF 936C>T polymorphism and breast cancer risk: evidence from 5,729 cases and 5,868 controls. Breast Cancer Res Treat 2011, 125(2):489-493.

167. Qiu LX, Wang K, Yang S, Mao C, Zhao L, Yao L, Zhang J, Zhang QL, Sun S, Xue K: Current evidences on vascular endothelial growth factor polymorphisms and breast cancer susceptibility. Mol Biol Rep 2011, 38(7):4491-4494

168. Yang DS, Park KH, Woo OH, Woo SU, Kim AR, Lee ES, Lee JB, Kim YH, Kim $J \mathrm{~S}$, Seo JH: Association of a vascular endothelial growth factor gene 936 $\mathrm{C} / \mathrm{T}$ polymorphism with breast cancer risk: a meta-analysis. Breast Cancer Res Treat 2011, 125(3):849-853.

169. Xu B, Li JM, Tong N, Tao J, Li PC, Song NH, Zhang W, Wu HF, Feng NH, Hua LX: VEGFA +936C>T polymorphism and cancer risk: a meta-analysis. Cancer Genet Cytogenet 2010, 198(1):7-14

170. Liu X, Wang Z, Yu J, Lei G, Wang S: Three polymorphisms in interleukin1 beta gene and risk for breast cancer: a meta-analysis. Breast Cancer Res Treat 2010, 124(3):821-825.

171. Oh JS, Kucab JE, Bushel PR, Martin K, Bennett L, Collins J, DiAugustine RP, Barrett JC, Afshari CA, Dunn SE: Insulin-like growth factor-1 inscribes a gene expression profile for angiogenic factors and cancer progression in breast epithelial cells. Neoplasia 2002, 4(3):204-217.

172. Cao C, Ying T, Fang JJ, Sun SF, Lv D, Chen ZB, Ma HY, Yu YM, Ding QL, Shu $\mathrm{LH}$, Deng Z-C: Polymorphism of vascular endothelial growth factor $-2578 \mathrm{C} / \mathrm{A}$ with cancer risk: evidence from 11263 subjects. Med Oncol 2011, 28(4):1169-1175.

173. Xue H, Lin B, Ni P, Xu H, Huang G: Interleukin-1B and interleukin-1 RN polymorphisms and gastric carcinoma risk: a meta-analysis. J Gastroenterol Hepatol 2010, 25(10):1604-1617.

174. Gao LB, Pan XM, Jia J, Liang WB, Rao L, Xue H, Zhu Y, Li SL, Lv ML, Deng W, Chen TY, Wei YG, Zhang L: IL-8-251A/T polymorphism is associated with decreased cancer risk among population-based studies: evidence from a meta-analysis. Eur J Cancer 2010, 46(8):1333-1343.
175. Liu L, Zhuang W, Wang C, Chen Z, Wu XT, Zhou Y: Interleukin-8-251 A/T gene polymorphism and gastric cancer susceptibility: a meta-analysis of epidemiological studies. Cytokine 2010, 50(3):328-334.

176. Peng B, Cao L, Wang W, Xian L, Jiang D, Zhao J, Zhang Z, Wang X, Yu L: Polymorphisms in the promoter regions of matrix metalloproteinases 1 and 3 and cancer risk: a meta-analysis of 50 case-control studies. Mutagenesis 2010, 25(1):41-48.

177. Wysoczynski M, Ratajczak MZ: Lung cancer secreted microvesicles: underappreciated modulators of microenvironment in expanding tumors. Int J Cancer 2009, 125(7):1595-1603.

178. Xie Y, Zhang H, Sheng W, Xiang J, Ye Z, Yang J: Adenovirus-mediated ING4 expression suppresses lung carcinoma cell growth via induction of cell cycle alteration and apoptosis and inhibition of tumor invasion and angiogenesis. Cancer Lett 2008, 271(1):105-116.

179. Gao Y, Cao Y, Tan A, Liao C, Mo Z, Gao F: Glutathione S-transferase M1 polymorphism and sporadic colorectal cancer risk: an updating metaanalysis and HuGE review of 36 case-control studies. Ann Epidemiol 2010, 20(2):108-121

180. Lu S, Wang Z, Cui D, Liu H, Hao X: Glutathione S-transferase P1 lle105Val polymorphism and breast cancer risk: a meta-analysis involving 34,658 subjects. Breast Cancer Res Treat 2011, 125(1):253-259.

181. Qiu LX, Yuan H, Yu KD, Mao C, Chen B, Zhan P, Xue K, Zhang J, Hu XC Glutathione S-transferase M1 polymorphism and breast cancer susceptibility: a meta-analysis involving 46,281 subjects. Breast Cancer Res Treat 2010, 121(3):703-708.

182. Singh V, Parmar D, Singh MP: Do single nucleotide polymorphisms in xenobiotic metabolizing genes determine breast cancer susceptibility and treatment outcomes? Cancer Invest 2008, 26(8):769-783.

183. Curran JE, Weinstein SR, Griffiths LR: Polymorphisms of glutathione S transferase genes (GSTM1, GSTP1 and GST1) and breast cancer susceptibility. Cancer Lett 2000, 153(1-2):113-120.

184. Economopoulos KP, Sergentanis TN, Vlahos NF: Glutathione S-transferase $\mathrm{M} 1, \mathrm{~T} 1$, and $\mathrm{P} 1$ polymorphisms and ovarian cancer risk: a meta-analysis. Int J Gynecol Cancer 2010, 20(5):732-737.

185. Zeng FF, Liu SY, Wei W, Yao SP, Zhu S, Li KS, Wan G, Zhang HT, Zhong M, Wang BY: Genetic polymorphisms of glutathione S-transferase T1 and bladder cancer risk: a meta-analysis. Clin Exp Med 2010, 10(1):59-68.

186. Moore LE, Baris DR, Figueroa JD, Garcia-Closas M, Karagas MR, Schwenn MR, Johnson AT, Lubin JH, Hein DW, Dagnall CL, Colt JS, Kida M, Jones MA, Schned AR, Cherala SS, Chanock SJ, Cantor KP, Silverman DT, Rothman N: GSTM1 null and NAT2 slow acetylation genotypes, smoking intensity and bladder cancer risk: results from the New England bladder cancer study and NAT2 meta-analysis. Carcinogenesis 2011, 32(2):182-189.

187. Tsukuda M, Nagahara T, Yago T, Matsuda H, Yanoma S: Production of granulocyte colony-stimulating factor by head and neck carcinomas. Biotherapy 1993, 6(3):183-187.

188. Lagadec PF, Saraya KA, Balkwill FR: Human small-cell lung-cancer cells are cytokine-resistant but NK/LAK-sensitive. Int J Cancer 1991, 48(2):311-317.

189. Enzmann V, Faude F, Kohen L, Wiedemann P: Secretion of cytokines by human choroidal melanoma cells and skin melanoma cell lines in vitro. Ophthalmic Res 1998, 30(3):189-194.

190. Kimura F, Nakamura Y, Sato K, Wakimoto N, Kato T, Tahara T, Yamada M, Nagata N, Motoyoshi K: Cyclic change of cytokines in a patient with cyclic thrombocytopenia. Br J Haematol 1996, 94(1):171-174.

191. Reinhold D, Bank U, Buhling F, Lendeckel U, Ulmer AJ, Flad HD, Ansorge S: Transforming growth factor-beta 1 (TGF-beta 1) inhibits DNA synthesis of PWM-stimulated PBMC via suppression of IL-2 and IL-6 production. Cytokine 1994, 6(4):382-388.

192. Nikolova PN, Pawelec GP, Mihailova SM, Ivanova MI, Myhailova AP, Baltadjieva DN, Marinova DI, Ivanova SS, Naumova EJ: Association of cytokine gene polymorphisms with malignant melanoma in Caucasian population. Cancer Immunol Immunother 2007, 56(3):371-379.

193. Freedman RS, Deavers M, Liu J, Wang E: Peritoneal inflammation a microenvironment for epithelial ovarian cancer (EOC). J Trans/ Med 2004, 2(1):23.

194. Jarnicki A, Putoczki T, Ernst M: Stat3: linking inflammation to epithelial cancer - more than a "gut" feeling? Cell division 2010, 5:14

195. Rundhaug JE, Fischer SM: Molecular mechanisms of mouse skin tumor promotion. Cancers 2010, 2(2):436-482.

196. Mischek D, Steinborn R, Petznek H, Bichler C, Zatloukal K, Sturzl M, Gunzburg WH, Hohenadl C: Molecularly characterised xenograft tumour 
mouse models: valuable tools for evaluation of new therapeutic strategies for secondary liver cancers. J Biomed Biotechnol 2009, 2009:437284.

197. Hiss D: Optimizing molecular-targeted therapies in ovarian cancer: the renewed surge of interest in ovarian cancer biomarkers and cell signaling pathways. Journal of Oncology 2012, 2012:737981.

198. LuO J, Solimini NL, Elledge SJ: Principles of cancer therapy: oncogene and non-oncogene addiction. Cell 2009, 136(5):823-837.

199. Chen Z, Yan B, Van Waes C: The role of the NF-kappaB transcriptome and proteome as biomarkers in human head and neck squamous cell carcinomas. Biomark Med 2008, 2(4):409-426.

200. Shimada Y, Imamura M: Prognostic factors for esophageal cancer-from the viewpoint of molecular biology. Gan To Kagaku Ryoho 1996, 23(8):972-981.

201. Ziober BL, Turner MA, Palefsky JM, Banda MJ, Kramer RH: Type I collagen degradation by invasive oral squamous cell carcinoma. Oral Oncol 2000, 36(4):365-372.

202. Nuovo GJ: In situ detection of PCR-amplified metalloproteinase CDNAs, their inhibitors and human papillomavirus transcripts in cervical carcinoma cell lines. Int J Cancer 1997, 71(6):1056-1060.

203. Liss C, Fekete MJ, Hasina R, Lam CD, Lingen MW: Paracrine angiogenic loop between head-and-neck squamous-cell carcinomas and macrophages. Int J Cancer 2001, 93(6):781-785.

204. Stachel D, Albert M, Meilbeck R, Kreutzer B, Haas RJ, Schmid I: Bone marrow Th2 cytokine expression as predictor for relapse in childhood acute lymphoblastic leukemia (ALL). Eur J Med Res 2006, 11(3):102-113.

205. Melinceanu L, Sarafoleanu C, Lerescu L, Tucureanu C, Caras I, Salageanu A: Impact of smoking on the immunological profile of patients with laryngeal carcinoma. J Med Life 2009, 2(2):211-218.

206. Lazar-Molnar E, Hegyesi H, Toth S, Falus A: Autocrine and paracrine regulation by cytokines and growth factors in melanoma. Cytokine 2000 12(6):547-554.

207. Inoue K, Wood CG, Slaton JW, Karashima T, Sweeney P, Dinney CP: Adenoviral-mediated gene therapy of human bladder cancer with antisense interleukin-8. Oncol Rep 2001, 8(5):955-964.

208. Snarskaia ES, Molochkov VA, Frank GA, Zavalishina LA: Matrix metalloproteinases and their tissue inhibitors in basal cell and metatypical cancer of the skin. Arkhiv Patologii 2005, 67(3):14-16.

209. Lievre A, Milet J, Carayol J, Le Corre D, Milan C, Pariente A, Nalet B, Lafon J, Faivre J, Bonithon-Kopp C, Olschwang S, Bonaiti-Pellié C, Laurent-Puig P, Members of the ANGH group: Genetic polymorphisms of MMP1, MMP3 and MMP7 gene promoter and risk of colorectal adenoma. BMC Cancer 2006, 6:270.

210. Ricketts C, Zeegers MP, Lubinski J, Maher ER: Analysis of germline variants in CDH1, IGFBP3, MMP1, MMP3, STK15 and VEGF in familial and sporadic renal cell carcinoma. PLoS One 2009, 4(6):e6037.

211. Esteller M, Garcia A, Martinez-Palones JM, Xercavins J, Reventos J: Susceptibility to endometrial cancer: influence of allelism at p53, glutathione S-transferase (GSTM1 and GSTT1) and cytochrome P-450 (CYP1A1) loci. Br J Cancer 1997, 75(9):1385-1388.

212. Kozhemiakin LA, Bulavin DV, Morozov VI, Osipov EV, Zolotarev DV: Effectiveness of the glutathione s-transferase assay in diagnosing lung cancer. Vopr Onkol 1995, 41(1):33-38.

213. Schilthuizen C, Broyl A, van der Holt B, de Knegt $Y$, Lokhorst $H$, Sonneveld P: Influence of genetic polymorphisms in CYP3A4, CYP3A5, GSTP1, GSTM1, GSTT1 and MDR1 genes on survival and therapy-related toxicity in multiple myeloma. Haematologica 2007, 92(2):277-278.

214. Lavender NA, Benford ML, VanCleave T, Brock GN, Kittles RA, Moore JH, Hein DW, Kidd LC: Examination of polymorphic glutathione S-transferase (GST) genes, tobacco smoking and prostate cancer risk among men of African descent: a case-control study. BMC Cancer 2009, 9:397.

215. Saadat I, Saadat M: The glutathione S-transferase mu polymorphism and susceptibility to acute lymphocytic leukemia. Cancer Lett 2000 158(1):43-45.
216. Ovsepian VA, Vinogradova E, Sherstneva ES: Cytochrome P4501A1, glutathione S-transferase M1 and T1 gene polymorphisms in chronic myeloid leukemia. Genetika 2010, 46(10):1360-1362.

217. Vrana D, Pikhart H, Mohelnikova-Duchonova B, Holcatova I, Strnad B, Slamova A, Schejbalova M, Ryska M, Susova S, Soucek P: The association between glutathione S-transferase gene polymorphisms and pancreatic cancer in a central European Slavonic population. Mutat Res 2009 680(1-2):78-81.

doi:10.1186/1479-7364-7-14

Cite this article as: Lanara et al:: Comparative study and meta-analysis of meta-analysis studies for the correlation of genomic markers with early cancer detection. Human Genomics 2013 7:14.

\section{Submit your next manuscript to BioMed Central and take full advantage of:}

- Convenient online submission

- Thorough peer review

- No space constraints or color figure charges

- Immediate publication on acceptance

- Inclusion in PubMed, CAS, Scopus and Google Scholar

- Research which is freely available for redistribution 